\title{
Water Quality Assessment of Streams Draining the Akwapim Ridge of Ghana
}

\author{
V. K. Nartey ${ }^{1 *}$, R. K. Adaboh ${ }^{2}$, J. R. Fianko ${ }^{3}$ and A. Donkor ${ }^{4}$ \\ 1,2,3 Department of Chemistry, University of Ghana, Legon, Ghana \\ ${ }^{4}$ Department of Environmental Engineering Sciences, University of Florida, Gainsville, USA \\ *Corresponding author
}

\begin{abstract}
Surface water samples from seven streams on the Akwapim Ridge were analysed over a period of 1 year for various water quality parameters following standard methods prescribed in APHA, AWWA, WEF and AOAC. The study was carried out in order to assess the suitability of the streams for drinking and other domestic purposes. Additionally, the effect of land use activities was assessed. The study revealed that, generally, most of the physico-chemical parameters of the streams were below the World Health Organization (WHO) limits recommended for drinking water, with the exception of the levels of sulphate and conductivity in three of the streams (Opiafo: $224 \mathrm{mg} / 1,908.5 \mu \mathrm{S} / \mathrm{cm}$; Kwati: $221.3 \mathrm{mg} / 1$, $920 \mu \mathrm{S} / \mathrm{cm}$; and Ademi: $246 \mathrm{mg} / 1,1292 \mu \mathrm{S} / \mathrm{cm}$ ), respectively, which were above the WHO requirements. Nevertheless, taking these factors into consideration (except the sulphate and conductivity), the waters may be regarded as excellent and good for drinking and other domestic uses.
\end{abstract}

\section{Introduction}

Water, the source of life and human civilization has become one of the major issues of the 21st century. It is probably the most valuable natural resource available to man, without which nothing can survive. Unfortunately, in many areas of the world, it is not possible to obtain a ready source of pure drinking water. In addition to this, no other public health issue affects a large proportion of the population than that of drinking water. Thus, through the ages, the contamination of drinking water by both point (e.g. sewage disposal) and non-point (runoff from agricultural farms) sources of pollution have resulted in several catastrophes and human death.

The supply of fresh water is an important role of rivers, springs and streams. For this reason, the quality of drinking water must be constantly monitored. Water quality relates to the chemical, physical and biological characteristics of water. The quality is often affected by both natural (e.g. types of soil, rocks and surface through which it flows) and anthropogenic activities (e.g. agricultural activities and mining). Hence, the key is to ensure the quality of water resources is suitable for their intended uses. For, it has long been realized that other substances dissolve and/or suspended in it can affect the suitability of water for any purpose (Faniran et al., 2001). Consequently, water must be substantially free from bacterial contamination, animal waste, chemical and other physical parameters to be potable and, thus, suitable for human consumption. Thus, currently, water pollution has become a major subject of public concern the world over. Despite the large volume of water that covers the surface of the earth, only $1 \%$ is inland or fresh and easily available for human use (Bockris, 1978). In Ghana, only 30\% of Ghanaians have access to safe drinking water. Over 50\% of Ghanaians use naturally “unprotected” source of water (Ministry of Health, Accra).

The Akwapim Ridge in the Eastern Region of Ghana is no exception. The nature of the area has made it such that the indigenous population uses surface waters such as rivers, streams, ponds and springs as their only source of potable water. The qualities of these water bodies vary naturally and widely depending on climate, season, and the geology of the local bedrock. Natural variations can have a negative impact on the suitability of water for human use, in addition to the contributions emanating from human activities like agricultural practices, which is characteristic of this part of Ghana. Not only does this phenomenon pose a problem to us all but it does not augur well for any sustainable development. These surface waters may be prone to pollution. It is, therefore, imperative to carry out an extensive baseline surface water quality assessment and management evaluation study of the Akwapim Ridge before deciding whether it is necessary to carry out monitoring or not.

The present study, the first in a series, focused on the water quality assessment of the springs/streams on the Akwapim Ridge to evaluate their suitability for domestic uses. It also aimed at identifying potential sources of pollution into the springs/streams. Biological characteristics could not be assessed at this stage.

\section{Material and methods}

Study area

The Akwapim Ridge (Fig. 1), is geogra-phically located approximately between latitudes $5^{0} 45^{\prime} \mathrm{N}$ and $6^{0} 05^{\prime} \mathrm{N}$ and longitudes $0^{\circ} 0^{\prime} \mathrm{W}$ and $0^{\circ} 14^{\prime} \mathrm{W}$. The area is found in the coastal savanna vegetation zone which experiences two rainy seasons, May-July and September -November, each year. The geological formation of the area is referred to as Dahomeyan. 


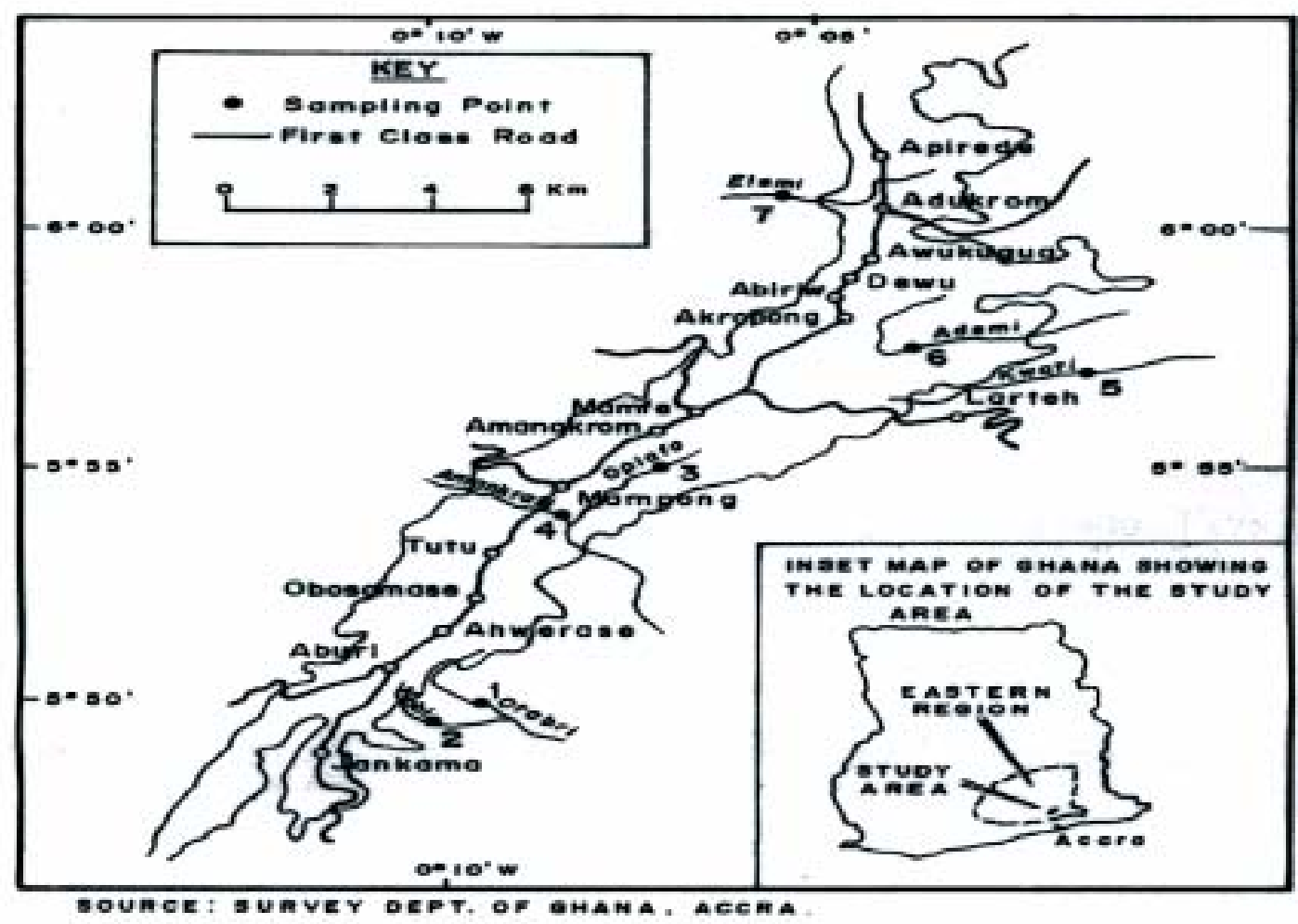

9

Fig. 1. Akwapim Ridge showing the sturdy area and sampling sites

The area consists of 17 major towns and a large number of surrounding villages. It is sandwiched between two major cities, Accra, the nation's capital, and Koforidua, the eastern regional capital. It has a population of about 221,100 people out of which 136,034 are rural dwellers. The area is fast becoming tourist attraction with its numerous tourist sites. Notable among them are the famous Aburi Botanical Gardens, the Proverbial Tetteh Quarshie cocoa farm and the Centre for Scientific Research into Plant Medicine at Mampong . Fig. 1 shows the study area and sampling sites.

\section{Sample methods and analysis}

Surface water samples were collected from seven springs/streams on the Akwapim Ridge during the wet and dry seasons in 2001. For the purpose of this write up, the different sampling points are given the designations as presented in Table 1. Water samples were collected mid-stream at depths $20-30 \mathrm{~cm}$ in order to obtain representative samples that are devoid of atmospheric influence. Twenty parameters have been evaluated in each sample. The $p H$ and water temperatures were mea-sured in the afternoon on the field using a portable $p \mathrm{H}$ meter and mercury-in-glass thermometer, respectively. All 1-litre polyethylene bottles used were cleaned with detergent, thoroughly rinsed with tap water, soaked in $10 \% \mathrm{HNO}_{3}$ solution overnight and finally rinsed with doubly de-ionised water. For sample collection, bottles were rinsed three times with stream water before filled. The water samples for analysis of trace 
metals were immediately acidified $\left(1 \% \mathrm{HNO}_{3}\right)$. After sample collection, and during transportation to the laboratory, samples were stored on ice pack in coolers.

TABLE 1

Description of sampling site

$\begin{array}{lll}\text { Name Of Stream } & \text { Location } & \text { Sampling Point } \\ \text { Otobri } & \text { Aburi } & \text { AB1 } \\ \text { Kobi (Jamaica) } & \text { Aburi } & \text { AB2 } \\ \text { Opiafo } & \text { Mampong } & \text { MG1 } \\ \text { Amankrate } & \text { Mampong } & \text { MG2 } \\ \text { Kwati } & \text { Larteh } & \text { LT } \\ \text { Ademi } & \text { Akropong } & \text { AK } \\ \text { Elemi } & \text { Adukrom } & \text { AD }\end{array}$

All samples were later filtered through a pre-cleaned glass filter. Analytical parameters were determined with reference to official methods currently suggested (APHA, AWWA, WEF, 1998; Kenneth, 1990). Samples for biochemical oxygen demand (BOD) were collected into dark brown bottles and incubated at $20{ }^{\circ} \mathrm{C}$ for 5 days before analysis. Trace metals as well as major cations $\left(\mathrm{Na}^{+}, \mathrm{K}^{+}, \mathrm{Ca}^{2+}, \mathrm{Mg}^{2+}\right)$ were analysed by flame atomic absorption spectrometer (Perkin 3110). The dichromate closed tube and Winkler's azide modification methods were used for chemical oxygen demand (COD) and dissolved oxygen (DO), respectively. BOD was determined as the difference between DO of sample for day one and day five for the same sample after incubation at $20{ }^{\circ} \mathrm{C}$ for 5 days. The nutrients (phosphate, nitrate and sulphate) were measured by 6100 visible range spectrometer. Total dissolved solids (TDS) were gravimetrically determined and total hardness, alkalinity and chloride were by titrimetric methods. All reagents were analytical grade and instruments pre-calibrated prior to measurement. Replicate analyses were carried out for each determination to ascertain reproducibility and quality assurance.

\section{Results and discussion}

The field and laboratory results of streams on the Akwapim Ridge at different seasons are presented in Tables 2a-2e, alongside the natural background levels for tropical surface waters (Stumm \& Morgan, 1981) and WHO for drinking water (WHO, 1996).

TABLE 2a

Physico - chemical parameters of water samples collected in the dry season (Nov. - Feb. 2001)

$\begin{array}{llllllll}\text { Parameter } & A B I & A B 2 & M G 1 & M G 2 & L T & A K & A D \\ p \text { H6.6 } & 6.7 & 7.2 & 6.7 & 7 & 6.1 & 6.2 & \\ \text { Temperature } & 25 & 26.5 & 27 & 27 & 27 & 25 & 27 \\ \text { TDS } & 430 & 440 & 640 & 610 & 650 & 770 & \text { nd } \\ \text { Cond. } & 411 & 240 & 1167 & 294 & 951 & 1400 & 175 \\ \text { DO } & 4.3 & 2.8 & 3 & 4.3 & 4 & 3.3 & 3 \\ \text { BOD } & 1.9 & 1.6 & 0.7 & 1.2 & 1 & 0.8 & 0.5 \\ \text { Hardness } & 50 & 55 & 101 & 61 & 74 & 74 & 26 \\ \text { Alkalinity } & 60 & 70 & 240 & 80 & 80 & 32 & 34\end{array}$

TABLE $2 b$

Physico - chemical parameters of water samples collected in the rainy season (May - Sept. 2001)

$\begin{array}{llllllll}\text { Parameter } & A B I & A B 2 & M G 1 & M G 2 & L T & A K . & A D \\ p \text { H6.3 } & 6 & 6.8 & 6.6 & 6.8 & 6.3 & 6.5 & \\ \text { Temperature } & 25 & 27 & 25 & 25 & 24 & 26 & 28 \\ \text { TDS } & 120 & \text { nd } & 360 & 240 & 380 & 963 & 430 \\ \text { Cond. } & 210 & 520 & 650 & 470 & 889 & 1184 & 414\end{array}$




$\begin{array}{llllllll}\text { DO } & 5.6 & 3.1 & 4.1 & 3.4 & 3.3 & 6.2 & 3.3 \\ \text { BOD } & 2.3 & 0.2 & 1.3 & 0.6 & 0.3 & 3.4 & 0.9 \\ \text { COD } & 43.2 & 48 & 48 & 56 & 46.4 & 46.4 & 39.2 \\ \text { Hardness } & 40 & 72 & 140 & 84 & 140 & 56 & 50 \\ \text { Alkalinity } & 24 & 20 & 102 & 42 & 62 & 22 & 28\end{array}$

Temperature ${ }^{0} \mathrm{C}$, TDS mg/l, Cond. $\mu \mathrm{S} / \mathrm{cm}$, DO mg/l, BOD mg/l, COD mg/l, Hardness mg $\mathrm{CaCO}_{3} / \mathrm{l}, \mathrm{Alkalinity} \mathrm{mg} \mathrm{CaCO}_{3} / \mathrm{l}$

TABLE 2C

Major ions, trace metals and nutrient levels (all in mg/l) of waters collected in the dry season (Nov.-Feb. 2001)

$\begin{array}{llllllll}\text { Parameter } & \text { AB1 } & \text { AB2 } & \text { MG1 } & \text { MG2 } & L T & A K & A D \\ \mathrm{Cl}^{-134.7} & 127.7 & 195 & 131.2 & 106.4 & 149 & 95.7 & \\ \mathrm{SO}_{4}^{2-} & 362.7 & 107.1 & 128.4 & 104.2 & 239 & 265.4 & 135.4 \\ \mathrm{Na} 9.6 & 20.7 & 5.7 & 2.2 & \text { nd } & \text { nd } & \text { nd } & \\ \mathrm{K} 11.2 & 7.1 & 3.7 & 1.3 & \text { nd } & \text { nd } & \text { nd } & \\ \mathrm{PO}_{4}-\mathrm{P} & 0.01 & 0.02 & 0.02 & 0.01 & 0.04 & 0.01 & 0.05 \\ \mathrm{NO}_{3}-\mathrm{N} & 0.11 & 0.11 & 0.10 & 0.1 & 0.4 & 0.6 & 0.02 \\ \mathrm{~Pb} \mathrm{BDL} & \mathrm{BDL} & \mathrm{BDL} & \mathrm{BDL} & \mathrm{BDL} & \mathrm{BDL} & \mathrm{BDL} & \\ \mathrm{Zn} & 0.1 & 0.1 & <0.01 & <0.01 & 1.2 & <0.01 & 0.2 \\ \mathrm{Fe} & 0.1 & 0.2 & 0.9 & 0.8 & 0.3 & 0.1 & 2 \\ \mathrm{Mn} & 0.2 & 0.2 & 1.5 & 0.1 & 0.3 & 0.3 & 0.8 \\ \mathrm{Cu}<0.01 & <0.01 & <0.01 & <0.01 & <0.01 & <0.01 & <0.01 & \end{array}$

BDL : Below detection limit nd: not determined

TABLE 2d

Major ions, trace metals and nutrient levels (all in mg/l) in waters collected in the rainy season (May - Sept. 2001)

$\begin{array}{llllllll}\text { Parameter } & A B 1 & A B 2 & M G 1 & M G 2 & L T & A K & A D \\ \mathrm{Cl}^{-} 70.9 & 106.4 & 248.2 & 70.9 & 177.3 & 177.3 & 70.9 & \\ \mathrm{SO}_{4}^{2-} & \text { nd } & 99.8 & 319.6 & 124.6 & 203.6 & 226.6 & 109.8 \\ \mathrm{Na} 5 & 3.5 & 16.6 & 14.7 & 15.2 & 26.1 & 17.6 & \\ \mathrm{~K} 4.4 & 1.7 & 13.5 & 5.7 & 12.9 & 19.9 & 2.7 & \\ \mathrm{PO}_{4}-\mathrm{P} & 0.06 & 0.04 & 0.07 & 0.06 & 0.08 & 0.08 & 0.05 \\ \mathrm{NO}_{3}-\mathrm{N} & 0.02 & <0.001 & 0.4 & 0.23 & \text { nd } & \text { nd } & \text { nd } \\ \mathrm{Pb} \mathrm{BDL} & \mathrm{BDL} & \mathrm{BDL} & \mathrm{BDL} & \mathrm{BDL} & \mathrm{BDL} & \mathrm{BDL} & \\ \mathrm{Zn} & 0.1 & 0.1 & 0.1 & 0.1 & 0.1 & 0.1 & 0.6 \\ \mathrm{Fe} & 0.2 & 0.3 & 0.5 & 0.6 & 0.2 & 0.2 & 3.5 \\ \mathrm{Mn} & 0.4 & 2.7 & 0.5 & 0.1 & 0 & 0.2 & 1 \\ \mathrm{Cu}<0.01 & <0.01 & <0.01 & <0.01 & <0.01 & <0.01 & <0.01 & \end{array}$

BDL: Below detection limit nd: not determined

TABLE 2e

Mean values of physico- chemical parameters of water samples collected over the entire sampling period for each location/site

$\begin{array}{llllllll}\text { Parameter } & A B 1 & A B 2 & M G 1 & M G 2 & L T & A K & A D \\ \text { pH6.5 } & 6.4 & 7 & 6.6 & 6.9 & 6.2 & 6.3 & \\ \text { Temp. } & 25 & 26.8 & 26 & 26 & 25.5 & 25.5 & 27.5 \\ \text { TDS } & 275 & - & 500 & 425 & 515 & 866.5 & \text { nd } \\ \text { Cond. } & 310.5 & 380 & 908.5 & 382 & 920 & 1292 & 294.5 \\ \text { DO } & 4.9 & 2.95 & 3.5 & 3.8 & 3.6 & 4.8 & 3.1 \\ \text { BOD } & 2.1 & 0.9 & 1.01 & 0.9 & 0.7 & 2.7 & 0.7\end{array}$




$\begin{array}{llllllll}\mathrm{COD} & \text { nd } & \text { nd } & \text { nd } & \text { nd } & 43.2 & 37.2 & \text { nd } \\ \mathrm{Hardness} & 45 & 63.5 & 120.5 & 72.5 & 107 & 65 & 38 \\ \mathrm{Alk} . & 42 & 45 & 171 & 61 & 71 & 27 & 31 \\ \mathrm{SO}_{4}^{2-} & \text { nd } & 103.5 & 224 & 114 & 221.3 & 246 & 122.6 \\ \mathrm{Cl}^{-1} 102.8 & 117 & 221.6 & 101 & 141.8 & 163.1 & 83.3 & \\ \mathrm{Na} 7.3 & 12.1 & 11.2 & 8.5 & \text { nd } & \text { nd } & \text { nd } & \\ \mathrm{K} 7.8 & 4.4 & 8.6 & 3.5 & \text { nd } & \text { nd } & \text { nd } & \\ \mathrm{PO}_{4}-\mathrm{P} & 0.03 & 0.03 & 0.05 & 0.04 & 0.06 & 0.04 & 0.05 \\ \mathrm{NO}_{3}-\mathrm{N} & 0.1 & 0.1 & 0.3 & 0.2 & 0.2 & \text { nd } & \text { nd } \\ \mathrm{Pb} \mathrm{BDL}_{\mathrm{Zn}} & \mathrm{BDL} & \mathrm{BDL} & \mathrm{BDL} & \mathrm{BDL} & \mathrm{BDL} & \mathrm{BDL} & \\ \mathrm{Fe} & 0.1 & 0.1 & 0.05 & 0.05 & 0.65 & 0.05 & 0.4 \\ \mathrm{Mn} & 0.2 & 0.2 & 0.7 & 0.7 & 0.3 & 0.1 & 2.8 \\ \mathrm{Cu}<0.01 & 0.3 & 1.5 & 1 & 0.1 & 0.2 & 0.3 & 0.9\end{array}$

BDL: Below detection limit nd: not determined

The streams on the Akwapim Ridge showed seasonal variations of concentration of both physical and chemical parameters in the water samples analysed. The dry season registered elevated levels of most physical and chemical water quality parameters as compared to the rainy season. The observed elevation of the parameters could be attributed to higher rate of evaporation during the dry season. Flooding which characterises the wet season with its attendant problems of runoffs from farmlands and drains, in contrast, introduces all kinds of pollutants into the streams. The corresponding dilution effect of the runoffs decreases the concentration of most ions and metals and serves as a contributing factor to the observed trend as in Tables 2a and 2c as compared to Tables $2 \mathrm{~b}$ and 2d, respectively.

\section{Physical characteristics}

The water temperature varied from $24{ }^{\circ} \mathrm{C}$ in the wet season to $28{ }^{\circ} \mathrm{C}$ in the dry season with a mean annual temperature of $26{ }^{\circ} \mathrm{C}$. These values are within the natural background levels of $22-29{ }^{\circ} \mathrm{C}$ for waters in the tropics (Stumm \& Morgan, 1981). The slight increase in temperature as compared to the wet season may be attributed to the low cloud cover and direct sun rays as mentioned earlier. The mean $\mathrm{pH}$ also varied from 6.52, for example, Aburi (AB2, wet season) to 7.20 in the dry season for Mampong (MG1), which conform to values found in fresh water (Stumm \& Morgan, 1981). None of the TDS values recorded exceed the WHO recommended limit of $100 \mathrm{mg} / \mathrm{l}$ for drinking water (Stumm \& Morgan, 1981). However, the values registered at AK (963 mg/l), LT (650 mg/l) and MG1 (640 mg/l) in Tables 2a and 2b were quite high. AK recorded the highest mean TDS level of $866 \mathrm{mg} / \mathrm{l}$ (Fig. 2a) which is much closer to the WHO value. This can probably be attributed to the inflow of sewerage, urban runoffs, ground water seeping, and intensive vegetable farming along the banks of the stream, particularly during the rainy season. In addition, rock weathering and solid dissolution known to be very important determinants to dissolved solids concentration in water (McCutheon et al., 1983) may play a key role.

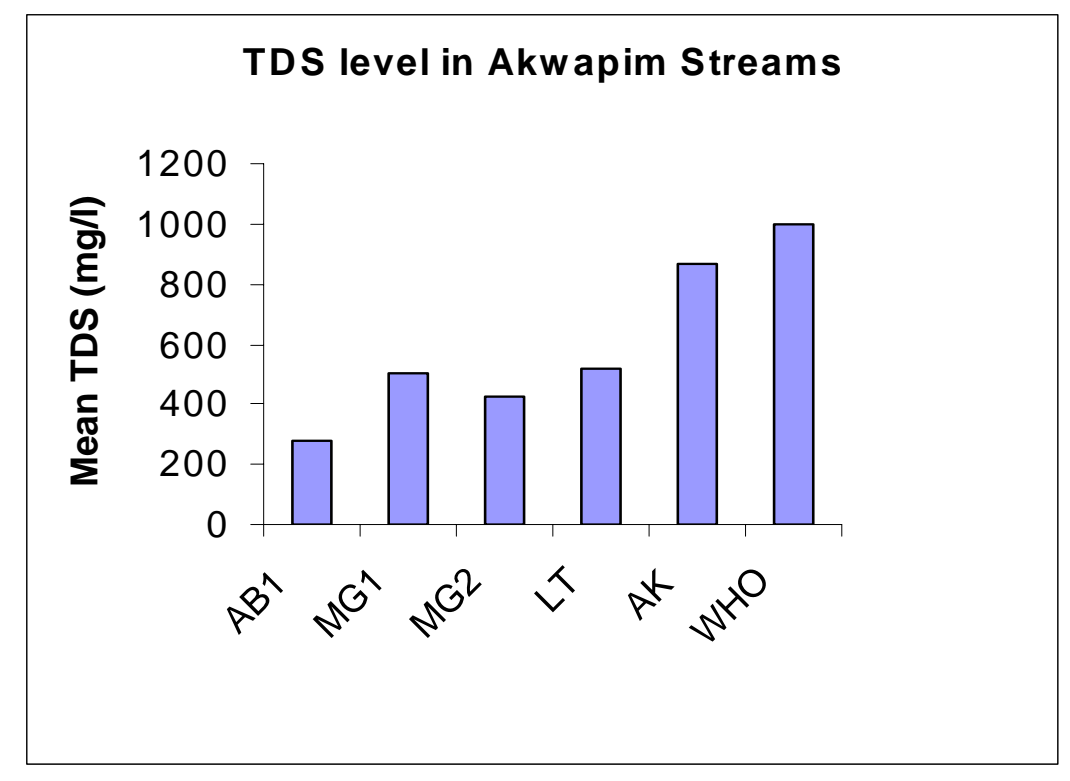

Fig. 2a. TDS levels in Akwapim streams 
The palatability of water with a TDS level less than $600 \mathrm{mg} / \mathrm{l}$ is generally considered to be good whereas water with TDS greater than $1200 \mathrm{mg} / \mathrm{l}$ becomes increasingly unpalatable (McCutheon et al., 1983). The mean conductivity levels of the streams are within the limits of acceptable standards, $700 \mu \mathrm{S} / \mathrm{cm}$ (WHO, 1984) for domestic water but were above the background range of 50-300 $\mu \mathrm{S} / \mathrm{cm}$, (Stumm \& Morgan, 1981). Most of the sampling points, however, registered values above the WHO recommended limits. The highest conductivity value was $1400 \mu \mathrm{S} / \mathrm{cm}$ at AK during the dry season in Akropong, and $1167 \mu \mathrm{S} / \mathrm{cm}$ at MG1 (Mampong) and $951 \mu \mathrm{S} / \mathrm{cm}$ at LT (Larteh) all in the dry season. The mean values for these streams over the entire sampling period were MG1 (908.5 $\mu \mathrm{S} / \mathrm{cm}), \mathrm{LT}(920$ $\mu \mathrm{S} / \mathrm{cm})$ and AK (1292 $\mu \mathrm{S} / \mathrm{cm})$ observed to be generally high (Fig. 2b). This is an indication of the extent of mineralization of these areas, sugges-tive of heavy impact of human activities on the streams. Thus, the elevated levels of conductivity could be attributed to drains from communities in the catch-ment areas of these streams and runoffs (carrying agro-chemicals) emerging from farming lands.

\section{Conductivity levels in Akwapim Streams}

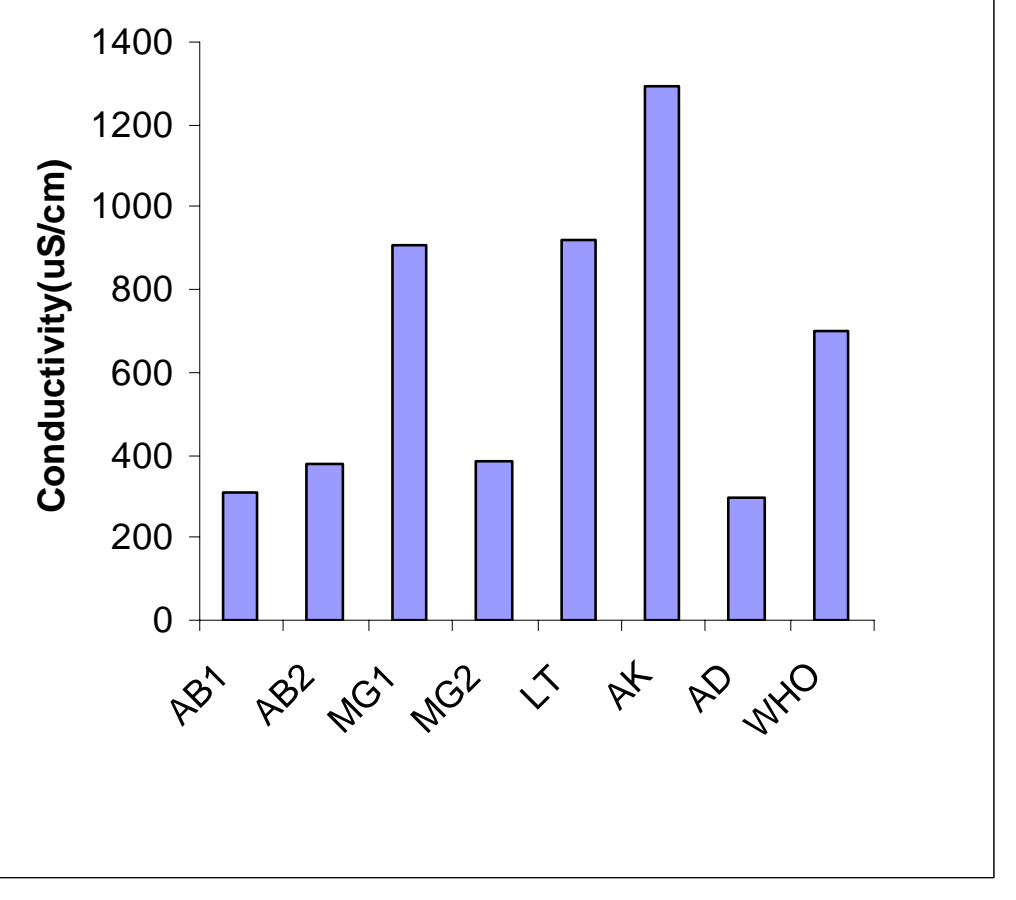

Fig. 2b. Conductivity levels of streams

\section{Chemical characteristics}

Alkalinity, total hardness, chemical oxygen demand (COD) and dissolved oxygen (DO) levels recorded were all within the WHO recommended limits for drinking water. Biochemical oxygen demand (BOD) measures the amount of biodegradable organic content in water. Natural waters with BOD value of $4 \mathrm{mg} / \mathrm{l}$ are considered to be slightly polluted with organic matter but safe for drinking (APHA, AWWA, WEF, 1998). The BOD values for all the streams sampled ranged between $0.2 \mathrm{mg} / \mathrm{l}$ at AB2 and $3.4 \mathrm{mg} / \mathrm{l}$ at AK in Akropong for the wet season (Table 2b). This is suggestive of low organic matter contamination of the water sampled. The overall mean value of $1.2 \mathrm{mg} / \mathrm{l}$ recorded fell within the WHO recommended value of $<3.0 \mathrm{mg} / \mathrm{l}$ for drinking water (WHO, 1996).

Despite the high oxygen value recorded for AK and AB1 (Tables 2b and 2e), their BOD values were also high especially during the wet season. This could be attributed to the fact that the right microbes for respiration of the organic materials were absent to utilize more of the dissolved oxygen in the breakdown of the organic matter. AK in Akropong had BOD value above the WHO recommended limit in the wet season. The AK stream might be receiving high organic waste from domestic waste water that is rich in organic matter from the Akropong township. Substantial amount of sulphate was detected in the area with some sampling stations registering values above the WHO recommended limit of $200 \mu \mathrm{g} / \mathrm{l}$ for drinking water. AB1 registered the highest value of $362.7 \mathrm{mg} / \mathrm{l}$ in the dry season, 
MG1 (224 $\mu \mathrm{g} / \mathrm{l})$, LT (221.3 $\mu \mathrm{g} / \mathrm{l})$ and AK (246 $\mu \mathrm{g} / \mathrm{l})$ were all above the WHO limit. These high levels were expected because of farming activities involving cultivation of vegetables along the banks of these streams. Runoffs from farms containing fertilizers and agro-chemicals find their way into the streams.

\section{Major ions}

MG1 and AK streams are characterized by high chloride concentration (Fig. 2c). According to the classification of Dallas \& Day (1993), chloride ions are non-cumulative toxins, however, excessive amounts of it, if taken over a long period of time, can constitute a health hazard. As can be seen in Tables 2c, 2d and 2e, chloride levels were almost up to the WHO limits of $250 \mathrm{mg} / \mathrm{l}$ for drinking water (Fig. 2c). Concentra-tions of $248 \mathrm{mg} / \mathrm{l}$ and $177.3 \mu \mathrm{g} / \mathrm{l}$ were found for MG1 and AK in the wet season, respectively, which could be due to the numerous farming activities along the banks of AK and MG1, and sewerage effluent from the upper parts of Mampong and Akropong townships.

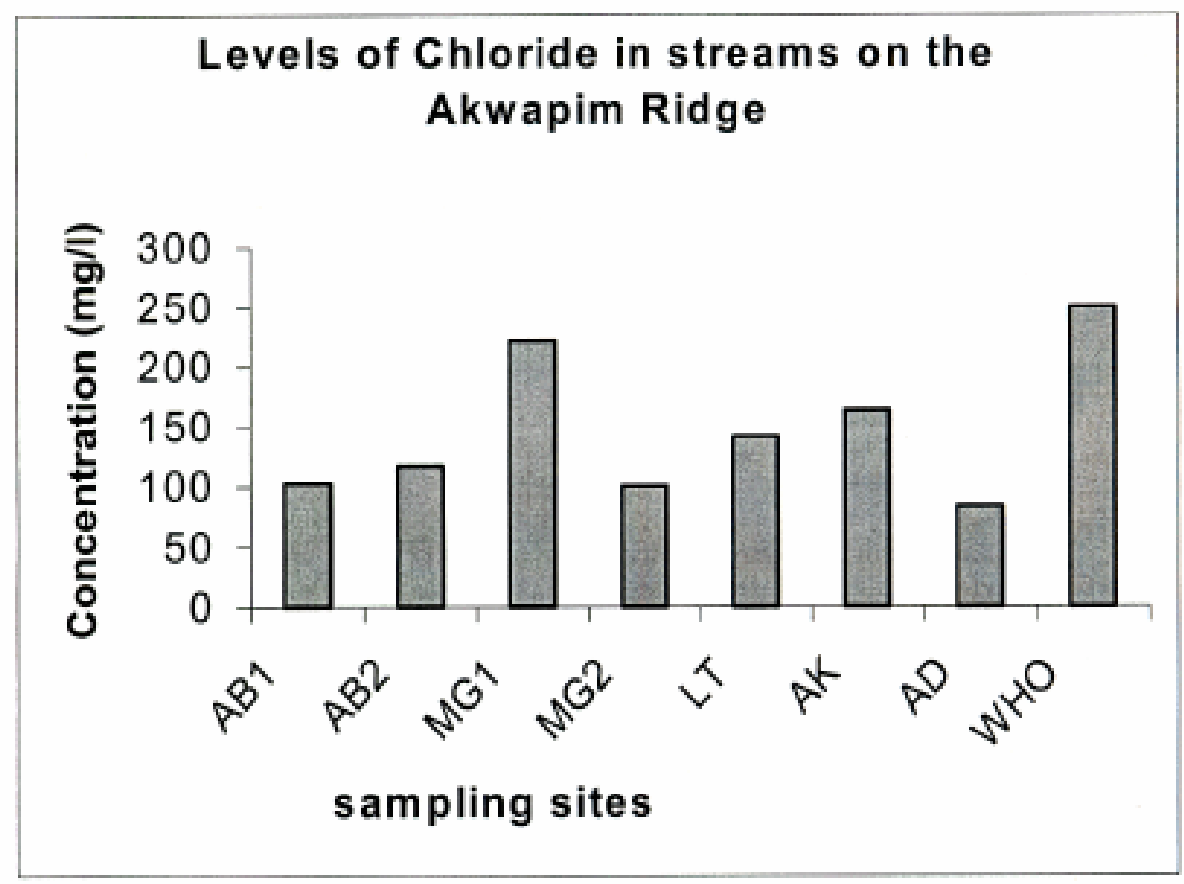

Fig. 2c. Mean chloride levels in Akwapim streams

\section{Nutrients}

The highest mean concentration of phosphate was registered at LT (0.1 mg/l) and that of nitrate was $0.3 \mathrm{mg} / \mathrm{l}$ at MG1. These levels may be attributed to sewerage-rich phosphate materials from the town and runoffs from farms along the banks of the streams. Nitrate and phosphate are the major nutrients in water for phytoplanktons growth and biological productivity, which could lead to eutrophication of the aquatic ecosystem (McCutheon et al., 1983). More-over, high levels of nitrate is known to cause methemoglobin "blue baby syndrome" in infants, and a suspect for stomach cancer in adults (Baird, 1995).

\section{Trace metals}

Trace metals concentrations in the streams were very low, because of low level of industrial activities on the Akwapim Ridge. Nevertheless, significant concentrations of metals were found at AD in Adukrom, AB2 in Aburi and MG1 in Mampong (Fig. 2d). The elemental occurrence was $\mathrm{Fe}>\mathrm{Mn}>\mathrm{Zn}>\mathrm{Cu}, \mathrm{Pb}$. The higher concentration of $\mathrm{Fe}$ and $\mathrm{Mn}$ in the water samples is a reflection of the geology of the mountains. Iron was the highest occurring metal with mean concentration of $0.7 \mathrm{mg} / \mathrm{l}$. MG1 had a mean concentration of $0.7 \mathrm{mg} / \mathrm{l}$, MG2 $0.7 \mu \mathrm{g} / \mathrm{l}$ and AD $2.8 \mathrm{mg} / \mathrm{l}$ which were all above the WHO limit of $0.30 \mathrm{mg} / \mathrm{l}$ for drinking water. The overall mean level of Mn was $0.6 \mathrm{mg} / \mathrm{l}$ which also exceeded the WHO limit of $0.1 \mathrm{mg} / \mathrm{l}$. The highest concentration of Mn (2.8 mg/l) was at AB2 and that of Fe (3.6 mg/l) was at $\mathrm{AD}$ in Adukrom recorded in the wet season. Though the presence of $\mathrm{Fe}$ and $\mathrm{Mn}$ in water are not hazardous to health, they are considered as aesthetic. However, high levels lead to reddish brown colouration resulting in staining of laundry and sanitary wares (WHO, 1996). 


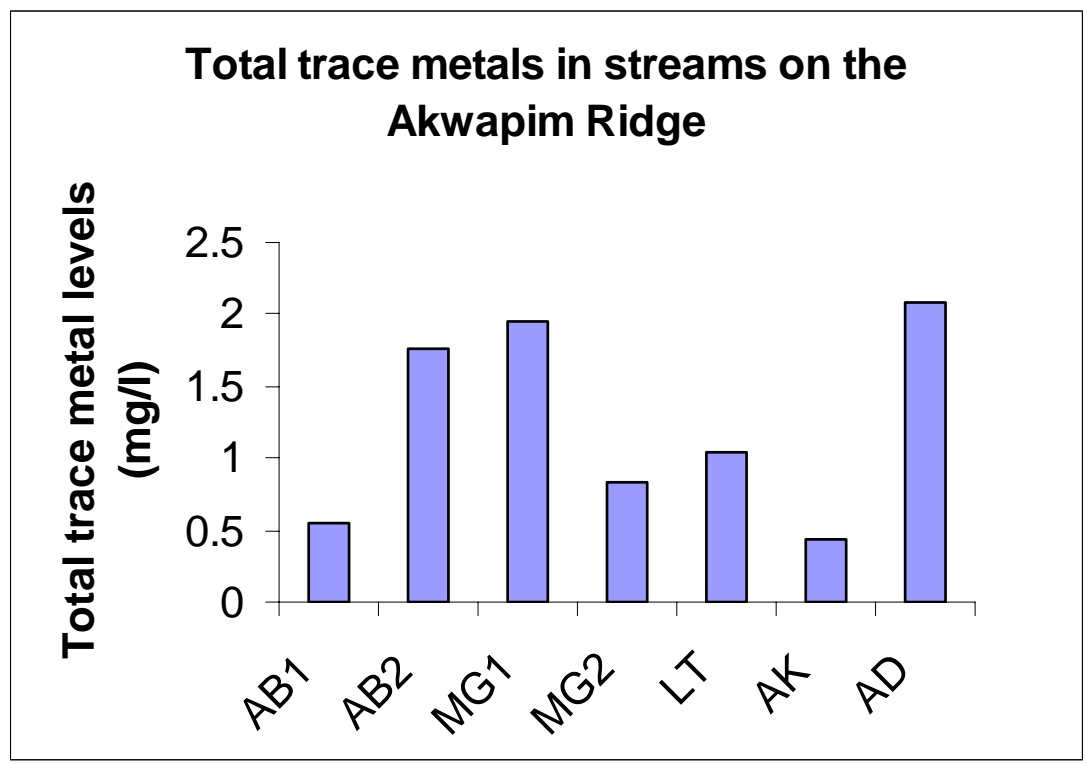

Fig. 2d. Mean levels of trace metals in Akwapim streams

\section{Conclusion}

The study revealed that most of the defined quality parameters of the streams on the Akwapim Ridge were below the WHO limits for drinking water and, therefore, may be suitable for domestic purposes. However, the levels of sulphates re-corded at MG1 (224 mg/l), LT (221 mg/l) and AK (246 mg/l) in addition to conductivity AK (1292 $\mu \mathrm{S} / \mathrm{cm}), \mathrm{LT}(920 \mu \mathrm{S} / \mathrm{cm})$ and MG1 $(908.5 \mu \mathrm{S} / \mathrm{cm})$ were above the recommended values (WHO, 1996). Thus, human activities along the banks of the streams and inflow of domestic sewerage from communities in the catchment areas, perhaps, have great impact on the water quality of the streams. Hence, these areas need attention to avoid long term pollution and destruction of the ecosystem. The Opiafo (MG1) stream was poor in water quality. As such, intermittent or constant monitoring is required to ensure water quality standards are achieved in the long run for the good of the inhabitants.

\section{Reference}

APHA, AWWA, WEF (1998). Standard methods for the examination of water and wastewater, 20 th edn. Washington, DC: APHA.

Baird C. (1995). Environmental chemistry, 2nd edn. New York: W. H. Freeman and Co.

Bockris J. O. M. (1978). Environmental chemistry. New York: Premium Press. 332 pp.

Dallas H. F. and Day J. A (1993). The effect of water quality variables on river and ecosystem. Water Research Commission Report. No. TT61/93.

Faniraan J. A., Ngceba F. S., Oche C. Y and Bhat R. B. (2001). "An assessment of water quality of the Isinuka Springs in the Transkei Region of Eastern Cape, Republic of South Africa” Wat. S. Afr. 27 (2): 241-250.

Kenneth H. (1990). Official methods of analysis, 15th edn., Vol. 1. Virginia, USA: AOAC Inc.

McCutcheon, S. C. Martin, J. L., Barnwell Jr T. O. (1983). Water quality. In Handbook of Hydrology. New York: McGraw-Hill Inc.

Ministry of Health (1999). Medium Term Health Strategy towards Vision 2020. Accra: Ministry of Health.

Stumm W. and Morgan J. J. (1981). Aquatic chemistry. New York: John Wiley and Sons.

WHO (1996). Guideline for drinking water quality, 2nd edn, pp. 351-354. Geneva: WHO.

WHO (1984). Guideline for drinking water quality Vol.1. 2nd edn. Geneva. WHO. 